\title{
A Facies Approach to the Stratigraphic Analysis of Late Wisconsinan Sediments in the Portal Creek Area, Jasper National Park, Alberta \\ L'analyse stratigraphique de sédiments du Wisconsinien supérieur par l'intermédiaire de la classification des faciès, région de Portal Creek, parc national de Jasper, Alberta Stratigraphische Analyse der Sedimente aus dem späten Wisconsin im Gebiet des Portal Creek, Jasper National Park, Alberta, mittels Fazies-Bestimmung
}

Victor Levson et Nathaniel W. Rutter

Volume 40, numéro 2, 1986

URI : https://id.erudit.org/iderudit/032633ar

DOI : https://doi.org/10.7202/032633ar

\section{Aller au sommaire du numéro}

\section{Éditeur(s)}

Les Presses de l'Université de Montréal

\section{ISSN}

0705-7199 (imprimé)

1492-143X (numérique)

\section{Découvrir la revue}

\section{Citer cet article}

Levson, V. \& Rutter, N. W. (1986). A Facies Approach to the Stratigraphic Analysis of Late Wisconsinan Sediments in the Portal Creek Area, Jasper National Park, Alberta. Géographie physique et Quaternaire, 40(2), 129-144. https://doi.org/10.7202/032633ar

\section{Résumé de l'article}

$\mathrm{Au}$ cours d'études régionales portant sur la stratigraphie, les diamictons d'origine glaciaire, d'abord décrits puis échantillonnés, ont été classés en différents faciès. La classification, fondée sur des critères objectifs de terrain, a été conçue en vue de l'interprétation génétique des dépôts nécessaire à l'établissement de bonnes corrélations stratigraphiques. L'analyse d'une séquence complexe de diamictons d'origine glaciaire de la région de Portal Creek a servi à vérifier les avantages d'une telle approche pour résoudre des problèmes d'ordre stratigraphique. L'interprétation génétique faite à partir des faciès a été corroborée par la concordance entre les séquences de faciès et s'est révélée efficace pour résoudre des problèmes de stratigraphie. Les études menées sur la stratigraphie et l'origine des sédiments de la région de Portal Creek font ressortir trois ensembles de sédiments, chacun d'origine différente, ce qui suppose l'existence de trois périodes glaciaires distinctes. Toutefois, l'analyse du milieu des dépôts démontre que les deux groupes de sédiments plus anciens ont probablement été mis en place au cours de la même période. On croit que les différences quant à l'origine s'expliquent par la prédominance périodique de l'un ou l'autre des deux glaciers de vallée qui s'écoulaient en confluence. L'analyse des faciès confirme les données stratigraphiques qui établissent que le troisième ensemble de sédiments se soit mis en place au cours d'un épisode glaciaire survenu plus tard. Bien que les corrélations stratigrpahiques entre les sédiments datés n'aient été établies qu'à titre d'essai, on croit que les épisodes glaciaires observés dans la stratigraphie de Portal Creek appartiennent tous au Wisconsinien supérieur. 


\title{
A FACIES APPROACH TO THE STRATIGRAPHIC ANALYSIS OF LATE WISCONSINAN SEDIMENTS IN THE PORTAL CREEK AREA, JASPER NATIONAL PARK, ALBERTA*
}

\author{
Victor LEVSON and Nathaniel W. RUTTER, Department of Geology, University of Alberta, Edmonton, Alberta T6G $2 E 3$.
}

\begin{abstract}
Glacial diamictons described and sampled during regional stratigraphic studies in Jasper National Park, Alberta, Canada, are categorized using a facies approach. The classification scheme is based on objective field criteria but it is designed to ultimately aid in genetic interpretations of the described deposits which are required for meaningful stratigraphic correlations. The utility of the facies approach in solving stratigraphic problems is tested by the analysis of a complex sequence of glacial diamictons in the Portal Creek area. Genetic interpretations placed on the facies were supported by general agreement between theoretical and observed facies sequences, and proved useful in solving stratigraphic problems. Stratigraphic and provenance studies in the Portal Creek region reveal three major sediment packages of distinct provenance indicating that three separate glacial episodes may have occurred. However, an environment analysis of the deposits shows that the oldest two groups of sediment probably were deposited during the same episode. Changes in till provenance are believed to be the result of fluctuations in the dominance of two confluent glaciers originating in different valleys. The facies analysis supports the stratigraphic evidence that the third sedimentary package was deposited in a distinct glacial episode at a significantly later time than the underlying deposits. Although stratigraphic correlations with dated sediments are tentative, both glacial events recorded in the Portal Creek stratigraphic record are presumed to be Late Wisconsinan in age.
\end{abstract}

RÉSUMÉ L'analyse stratigraphique de sédiments du Wisconsinien supérieur par l'intermédiaire de la classification des faciès, région de Portal Creek, parc national de Jasper, Alberta. Au cours d'études régionales portant sur la stratigraphie, les diamictons d'origine glaciaire, d'abord décrits puis échantillonnés, ont été classés en différents faciès. La classification, fondée sur des critères objectifs de terrain, a été conçue en vue de l'interprétation génétique des dépôts nécessaire à l'établissement de bonnes corrélations stratigraphiques. L'analyse d'une séquence complexe de diamictons d'origine glaciaire de la région de Portal Creek a servi à vérifier les avantages d'une telle approche pour résoudre des problèmes d'ordre stratigraphique. L'interprétation génétique faite à partir des faciès a été corroborée par la concordance entre les séquences de faciès et s'est révélée efficace pour résoudre des problèmes de stratigraphie. Les études menées sur la stratigraphie et l'origine des sédiments de la région de Portal Creek font ressortir trois ensembles de sédiments, chacun d'origine différente, ce qui suppose l'existence de trois périodes glaciaires distinctes. Toutefois, l'analyse du milieu des dépôts démontre que les deux groupes de sédiments plus anciens ont probablement été mis en place au cours de la même période. On croit que les différences quant à l'origine s'expliquent par la prédominance périodique de l'un ou l'autre des deux glaciers de vallée qui s'écoulaient en confluence. L'analyse des faciès confirme les données stratigraphiques qui établissent que le troisième ensemble de sédiments se soit mis en place au cours d'un épisode glaciaire survenu plus tard. Bien que les corrélations stratigrpahiques entre les sédiments datés n'aient été établies qu'à titre d'essai, on croit que les épisodes glaciaires observés dans la stratigraphie de Portal Creek appartiennent tous au Wisconsinien supérieur.
ZUSAMMENFASSUNG Stratigraphische Analyse der Sedimente aus dem späten Wisconsin im Gebiet des Portal Creek, Jasper National Park, Alberta, mittels Fazies-Bestimmung. Glaziale Diamiktons, die während regionaler stratigraphischer Studien zunächst beschrieben und von denen dann Proben genommen wurden, werden mittels einer $\mathrm{Fa}$ zies-Bestimmung klassifiziert. Das Klassifizierungsschema beruht auf objektiven FeldKriterien, aber es wurde letzten Endes als Hilfsmittel bei den genetischen Interpretationen der beschriebenen Ablagerungen erstellt, welche erforderlich sind, um sinnvolle stratigraphische Korrelationen zu erhalten. Der Nutzen der Fazies-Bestimmung bei der Lösung stratigraphischer Probleme wird mittels der Analyse einer komplexen Folge glazialer Diamiktons im Gebiet des Portal Creek überprüft. Studien der Stratigraphie und der Herkunft der Sedimente im Gebiet des Portal Creek zeigen drei Haupt-Sediment-Einheiten verschiedener Herkunft, was darauf schließen läßt, da $\beta$ drei voneinander unabhängige glaziale Episoden aufgetreten sein könnten. Indessen zeigt eine Umwelt-Analyse der Ablagerungen, da $\beta$ die zwei ältesten Sediment-Gruppen wahrscheinlich während derselben Episode abgelagert wurden. Veränderungen in der Herkunft des Till hält man für das Ergebnis des Wechsels im Einflu $\beta$ zweier aus unterschiedlichen Tälern kommenden Gletscher, die zusammenfließen. Die Fazies-Analyse stützt den stratigraphischen Nachweis, da $\beta$ die dritte Sediment-Einheit in einer anderen glazialen Episode abgelagert wurde, zu einer eindeutig späteren Zeit als die darunter liegenden Ablagerungen. Obwohl die stratigraphischen Korrelationen mit den datierten Sedimenten nur versuchsweise hergestellt wurden, werden beide glazialen Ereignisse, die in der Stratigraphie des Portal Creek festgehalten sind, als dem späten Wisconsin zugehörig betrachtet.

\footnotetext{
* Contribution du premier symposium de la CANQUA, sous la direction de René W. Barendregt.
} 


\section{INTRODUCTION}

Much research in glacial geology in recent years has concentrated on the genesis of tills and related deposits. Tills originate in complex depositional environments and an understanding of their genesis aids greatly in stratigraphic studies. Present till classification systems are genetically based (BOULTON, 1976; DREIMANIS, 1976, 1982a; HALDORSEN, 1982; and SHAW, 1982a) and, although they are useful in identifying the types of tills that may occur in an area, they require detailed field observations and, consequently, they are of restricted use in regional stratigraphic studies where large numbers of outcrops must be described in a short time. This paper uses a facies classification which is based on objective field criteria but was designed to provide information useful for the genetic interpretation of the described sediments. A similar lithofacies classification has recently been developed for deposits of continental glaciers in southern Alberta (PROUDFOOT, 1985).

The purpose of this paper is to illustrate the application of the lithofacies approach to glacial stratigraphy in the mountain environment. The Portal Creek area (Fig. 1) was chosen as the site of this case study for several reasons:

1) Several good exposures of glacial sediments, each containing a number of stratigraphic units, occur in the area.

2) Variations in the bedrock geology of surrounding regions makes till provenance, as determined by pebble lithology, a useful tool in providing some stratigraphic control.

3) A wide variety of facies are exposed in the area.

4) The Portal Creek sections are important to determining the glacial history of the Jasper region because they transect the possible terminal region of a distinct glacial event.

The sequence of deposits in the Portal Creek area is discussed within a stratigraphic context, beginning with the oldest sediments. Genetic interpretations of the deposits are also presented within this context. The stratigraphic implications of the environmental analysis are then discussed. Finally, the glacial history of the area is presented.

\section{REGIONAL SETTING}

The study area is located in the Rocky Mountains of westcentral Alberta, Canada, within Jasper National Park (Fig: 1). Jasper townsite (1058 $\mathrm{m}$ asl) lies approximately in the center of Jasper National Park. Relief in the region is high with mountain peaks commonly rising about $1500 \mathrm{~m}$ above valley bottoms.

The Portal Creek sections (Fig. 2) are located approximately $10 \mathrm{~km}$ south of Jasper townsite. The exposures occur in the vicinity of the junction of two major valleys that are oriented at near right angles. Portal Creek flows from the southwest (about $\left.250^{\circ}\right)$ into the northwest-southeast $\left(330^{\circ}\right.$ to $\left.150^{\circ}\right)$ trending Athabasca River valley. The deposits exposed along Portal Creek, therefore, were transported to the area by ice moving down the Athabasca valley and/or the Portal Creek valley.

\section{BEDROCK GEOLOGY}

The Portal Creek area lies within the Main Ranges of the Rocky Mountains Physiographic Region (BOSTOCK, 1970). The Main Ranges subprovince consists of thick, relatively flat lying, or gently dipping thrust blocks with broad folds and southwesterly dipping normal (gravity) faults (PRICE and MOUNTJOY, 1970). They are mainly composed of distinctly bedded carbonates, quartzitic sandstones, and shales of Cambrian and Pre-Cambrian age.

The local bedrock in the vicinity of the Portal Creek sections is largely Miette Group shale, sandstone, and conglomerate with minor siltstone and dolomite (MOUNTJOY and PRICE, 1985 ). Bedrock in the Athabasca valley south of the Portal Creek junction, consists of Miette Group rocks and Gog Group quartzitic sandstones, shales and minor dolomite (CAMPBELL, 1971). Quartzitic sandstones of the McNaughton Formation (Gog Group) dominate the higher elevations in the Portal Creek watershed. Middle Miette Group grit and sandstone, with some shale and siltstone outcrop in the lower Portal Creek watershed. The only major source of limestone in the region is carbonate formations in the upper Athabasca drainage basin (CAMPBELL, 1971).

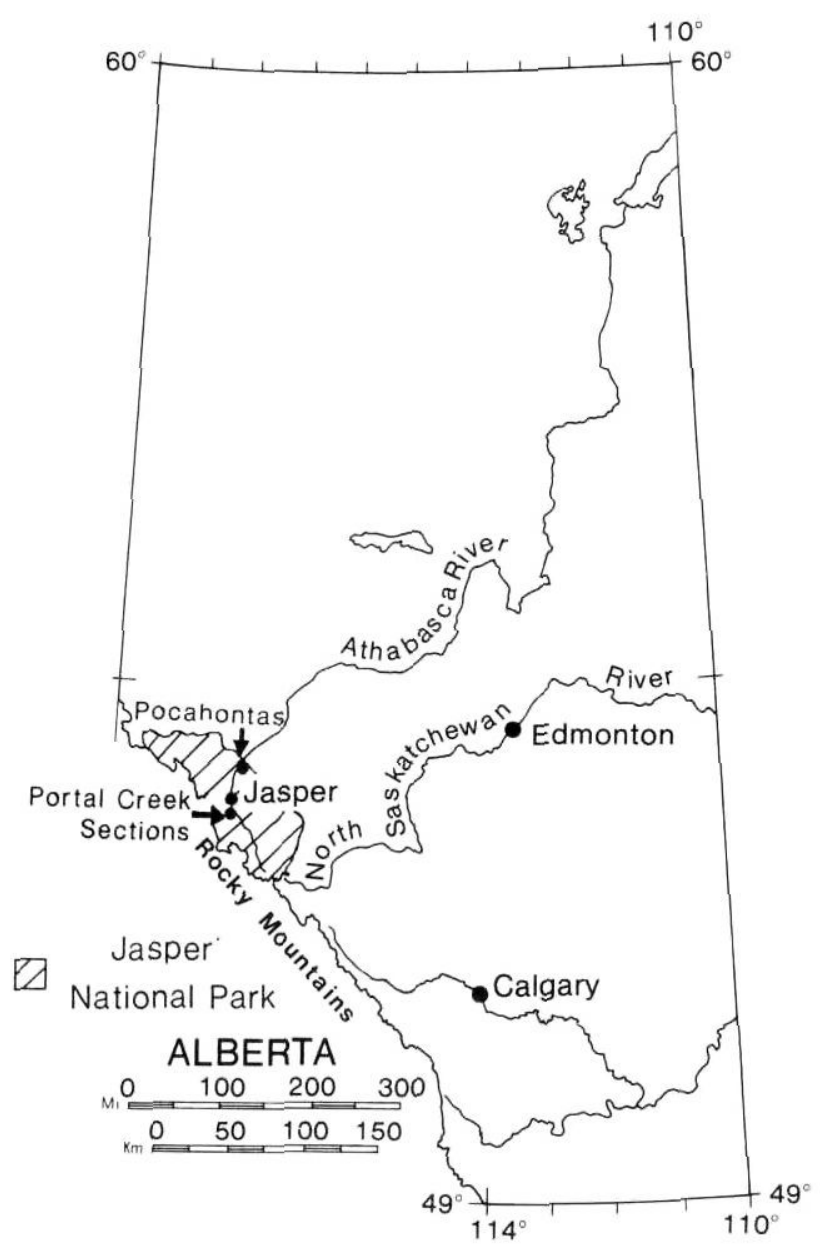

FIGURE 1. Location of study area.

Localisation de la région à l'étude. 


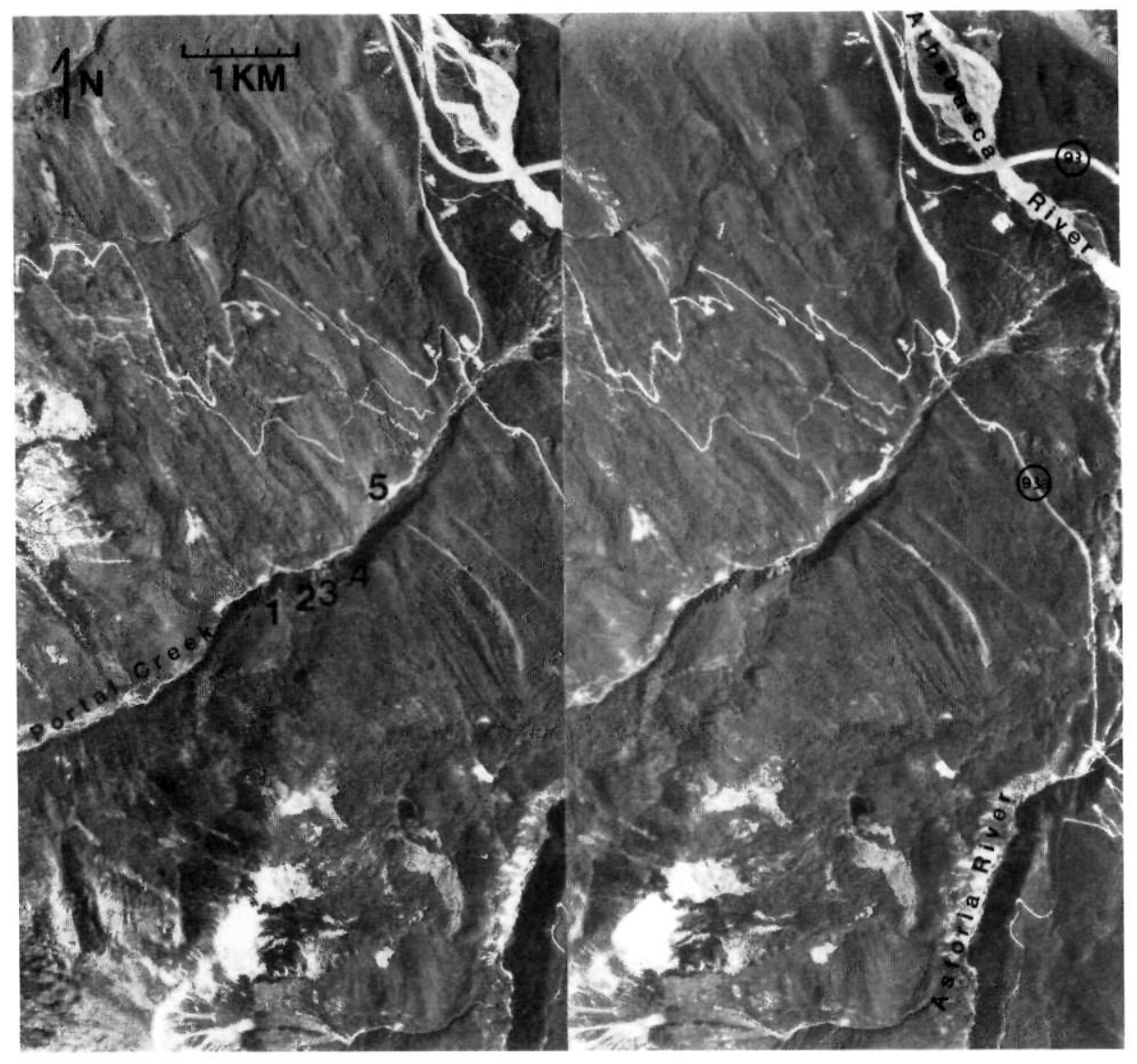

FIGURE 2. Stereopair of the Portal Creek area. Section locations are numbered 1 to 5 .

Stéréogramme de la région de Portal Creek. Les sites des coupes étudiées sont numérotés de 1 à 5.

These major differences in the bedrock composition between the Athabasca River and Portal Creek valleys, allow for the provenance of tills exposed in the area to be determined. Deposits originating in the Portal Creek valley should be enriched in coarse-grained clastic rocks and depleted in finegrained clastics, compared to deposits from the Athabasca Valley. Furthermore, deposits derived from the Portal Creek watershed should contain few or no limestone clasts since few or no limestone outcrops occur in the Portal Creek watershed.

The bedrock variability also aids in the genetic interpretation of tills in the region. For example, valley bottoms are dominated by pelitic rocks whereas higher elevations are dominated by coarse-grained clastics thus aiding in the distinction of supraglacially and subglacially derived sediments.

\section{SUMMARY OF FACIES PRESENT}

Eight facies of glacial diamicton have been recognized in Jasper National Park (Table I). The main diagnostic characteristics of each lithofacies are included in the facies name. Common characteristics and genetic interpretations of each facies are also provided in Table I. A detailed discussion of the criteria used in making the facies designations and their genetic interpretations are provided by LEVSON (1986).

Facies are defined on the basis of objective characteristics readily observable in the field. Since most glacial diamictons in the area are massive, the facies definitions are based on the nature of associated sorted and stratified materials, as well as on characteristic internal features of the diamictons themselves (mainly pebble fabric, banding, and grain size distribution of matrix and clasts). These criteria are similar to those used by other authors. LAWSON (1981), for example, identified 3 main criteria for distinguishing sediments in the modern glacial environment. These were pebble fabric, sedimentary structure (mainly of sorted and stratified sediments associated with the diamictons), and clast concentrations. These criteria have genetic implications and they are used in this study to designate different facies, so that depositional environments can ultimately be interpreted (WALKER, 1984). However, genetic interpretations are independent of the facies descriptions and are subject to revision.

Facies 8 does not occur in the Portal Creek area and is not discussed here. The seven facies found in the study area are:

1. Massive diamicton (Fig. 3);

2. Massive diamicton with abundant striated, faceted and 'embedded' clasts (Fig. 4). ('Embedded' clasts are those that are firmly fixed in surrounding materials. They often are in mutual contact, overlie compressively deformed sediments and occur at the base of massive diamicton.);

3. Banded (layered) diamicton (Fig. 5);

4. Massive diamicton containing sand and gravel lenses that are nearly circular in cross section (Fig. 6); 
Facies descriptions and interpretations

\begin{tabular}{ll}
\hline Type & \multicolumn{1}{c}{ Name } \\
\hline 1 & Massive diamicton \\
$1 \mathrm{a} \quad$ & $\begin{array}{l}\text { Massive diamicton with rare, } \\
\text { steeply dipping, sand and } \\
\text { gravel lenses and layers }\end{array}$ \\
1b & $\begin{array}{l}\text { Massive diamicton with rare, } \\
\text { plano-convex, sand and } \\
\text { gravel lenses } \\
\text { Massive diamicton with } \\
\text { abundant striated, faceted, } \\
\text { and embedded clasts }\end{array}$ \\
3 & $\begin{array}{l}\text { Banded (layered) diamicton } \\
\text { and }\end{array}$
\end{tabular}

4

Massive diamicton containing sand and gravel lenses circular in cross section

5
Bouldery diamicton with numerous, highly disturbed, sand and gravel lenses and layers

Massive to moderately stratified diamicton containing trough-shaped sand and gravel lenses

Intercalated diamicton, sand and gravel commonly with compressive deformation structures

Diamicton with abundant undisturbed, trough-shaped, sand and gravel lenses

Coarse textured diamicton interbedded with sands and gravels

Sandy diamicton interbedded with sands and gravels

Gravelly diamicton interbedded with sands and gravels

Massive diamicton interbedded with horizontally laminated silts and clays
Fine grained, dense, massive, matrix-supported diamicton; striated clasts of local lithology common; strong, unimodal pebble fabric, parallel to the valley; sharp basal contact

Characteristics as in facies 1 but with a consistent downvalley plunge of sand lenses and a-axis of elongated clasts

Characteristics as in facies 1 but with rare, horizontal, well stratified, plano-convex lenses

Massive, dense, fine grained, diamicton; abundant heavily striated clasts; faceted, embedded and fractured clasts common; strong, unimodal, pebble fabric, parallel to valley; lower contact sharp and planar

Diffuse, horizontal, diamicton bands (distinct mainly due to color and textural differences); bands may drape boulders; fine grained; low total clast content; unimodal, moderately strong, pebble fabric parallel to valley; lower contact gradational

Massive diamicton similar to type 1 but with sand and gravel lenses nearly circular in cross section (tubular sand bodies); stratification in lenses exibits normal faults and convolutions; moderate to weak, pebble fabric, unimodal to multimodal; lower contact gradational

Massive to weakly stratified diamicton; clasts of non-local lithology dominate; normally faulted, trough-shaped, sand and gravel lenses; irregular, thin, layers of sorted material; large angular clasts common; poorly compacted; intermediate matrix textures; moderate to weak pebble fabric (unimodal, bimodal or multimodal), high a-axis plunges; lower contact commonly gradational

Matrix to clast-supported diamicton with numerous troughshaped lenses and thin layers of sorted material; sorted beds may dip gently and are traceable for tens of meters; channel-fill cross-bedding common in lenses; lower contacts sharp to gradational

Diamicton dominates; sorted layers indistinct and may exhibit low angle faults, overturned folds and/or shear(?) structures

Diamicton less dominant than in $6 \mathrm{a}$; abundant, regularly shaped, sand and gravel lenses; diamicton sandier than $6 \mathrm{a}$; high upvalley a-axis plunges common

Massive to moderately stratified diamicton; high total clast contents; sand and gravel beds dominate; lower contacts conformable or erosional

Matrix-supported, sandy diamicton; some striated and subangular clasts; sands and gravels exhibit large changes in grain size distribution, sorting and bed orientation over short distances; load and fluid injection structures common

Gravelly, clast-supported, diamicton grades into moderately sorted gravels; sands and gravels generally horizontally bedded and well sorted

Matrix-supported, fine grained, diamicton; occasional convolute laminations; scattered pebbles in silts and clays; lower contacts irregular
Genetic Interpretation

Basal tills:

Basally derived tills of indeterminate origin

Lee-side till

Basal melt-out till

Subglacial lodgement till

Basal melt-out till

Englacial tills:

Melt-out till (from basal positions within ice)

Supraglacial tills:

Flow till

Icemarginal depositsProglacial (Frontal): Till flow, debris flow, and fluvial deposits

Proximal proglacial till flows with intermittent fluvial deposits

Distal, proglacial till flows with intermittent fluvial deposits

Icemarginal depositsProglacial and Lateral: Subaerial debris flow deposits and glaciofluvial outwash

Proximal flow till and subaerial debris flow deposits and ice-contact outwash

Subaerial debris flow deposits and proximal outwash

Subaquatic flow tills and glaciolacustrine sediments 


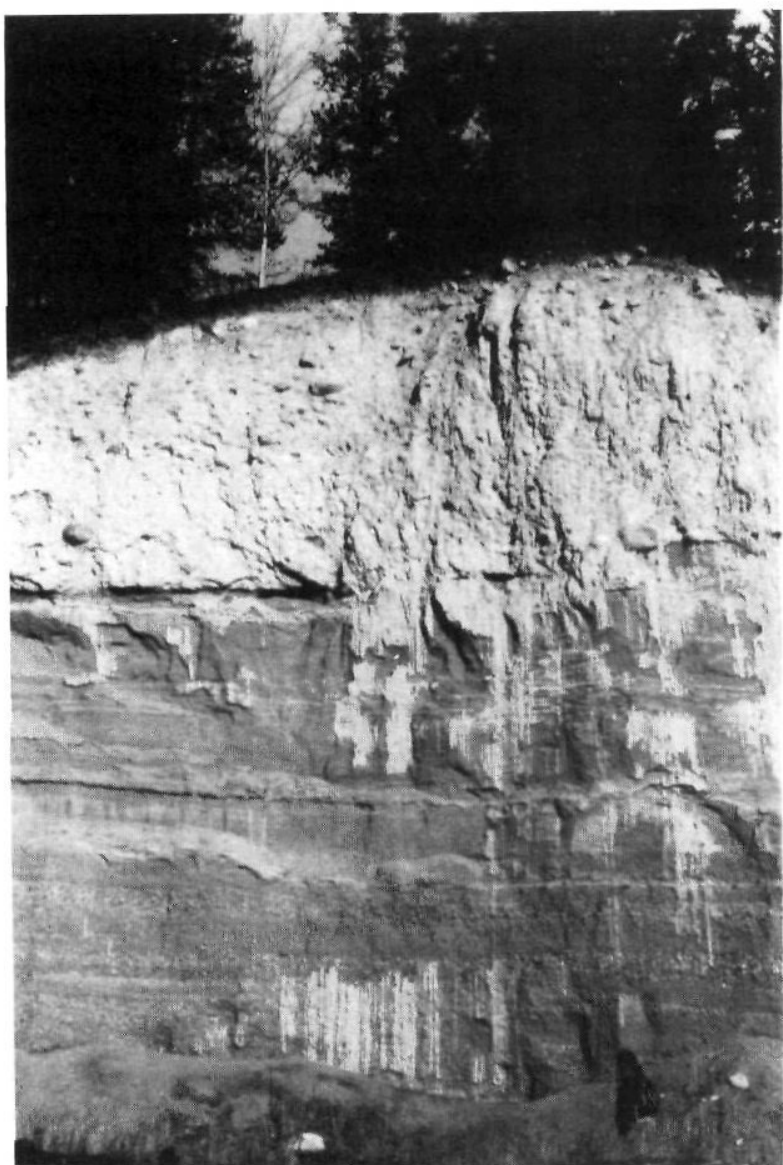

FIGURE 3. Massive diamicton (facies 1) overlying sands and gravels; note sharp, planar, erosional contact below diamicton; man in foreground for scale.

Diamicton massif (faciès $n^{\circ} 1$ ) recouvrant des sables et graviers; à remarquer le contact d'érosion net et plat (l'homme au premier plan sert d'échelle).

5. Bouldery diamicton with numerous, highly disturbed, sand and gravel lenses and layers (Fig. 7);

6. Massive to moderately stratified diamicton containing trough-shaped, sand and gravel lenses (Fig. 8). (Subfacies $6 \mathrm{a}$ is dominantly diamicton with disrupted stratification in the sorted materials; in subfacies $6 \mathrm{~b}$ the diamicton is less dominant and contains abundant undisturbed lenses.);

7. Coarse-textured diamicton interbedded with stratified sands and gravels (Fig. 9). (Diamicton of subfacies 7a is usually sandy and matrix-supported whereas $7 \mathrm{~b}$ is mainly gravelly and clast-supported.)

\section{STRATIGRAPHY}

Five exposures of Quaternary sediment along Portal Creek were described in detail in the field. The road to Marmot Basin ski area crosses Portal Creek and provides access to the sections (Fig. 10, inset map). Stratigraphic columns for each of these sections and a location map are provided in Figure 10. The stratigraphy of the Portal Creek region is discussed below

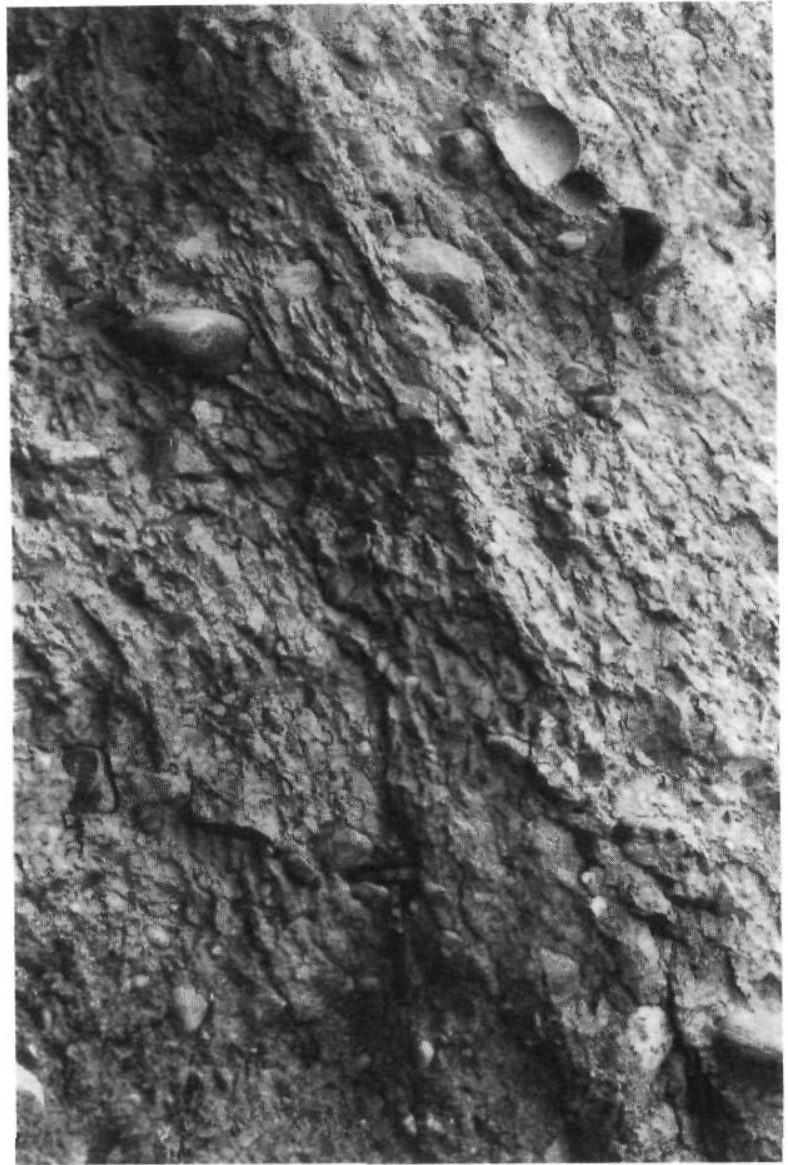

FIGURE 4. Massive diamicton with abundant striated, faceted and embedded clasts (facies 2): note clast concentration in lower part of photo near rock hammer.

Diamicton massif comprenant de nombreux fragments intercalés striés et à facettes (faciès $n^{\circ} 2$ ); à remarquer la concentration de fragments dans la partie inférieure près du pic.

by area. The three upper (southwestern most) sections, which are stratigraphically similar, are discussed together. A composite of these three sections is provided in Figure 11.

\section{LOWER PORTAL CREEK AREA}

The lowest exposed sediments in the lower Portal Creek area are clast-supported diamictons that grade into poorly stratified, coarse gravels interbedded with sands (Column 5 , Figure 10). Clasts are weakly imbricated and show no striations. They are mainly sandstone and quartzite $(60 \%)$, shale $(20 \%)$ and siltstone $(20 \%)$. Minor quantities of dolomite and no limestone are present, indicating a Portal Creek provenance. Strata dip gently $\left(2-5^{\circ}\right)$ to the northeast, parallel to the present day stream. The upper part of these sediments is interbedded with matrix-supported diamicton of facies $7 \mathrm{~b}$ (gravelly diamicton interbedded with sands and gravels). The diamicton occurs as beds up to $0.5 \mathrm{~m}$ thick that are laterally continuous for $20 \mathrm{~m}$ or more and have sharp, planar upper and lower contacts.

These sediments are unconformably overlain by moderately well sorted and stratified sands that are deformed, faulted 

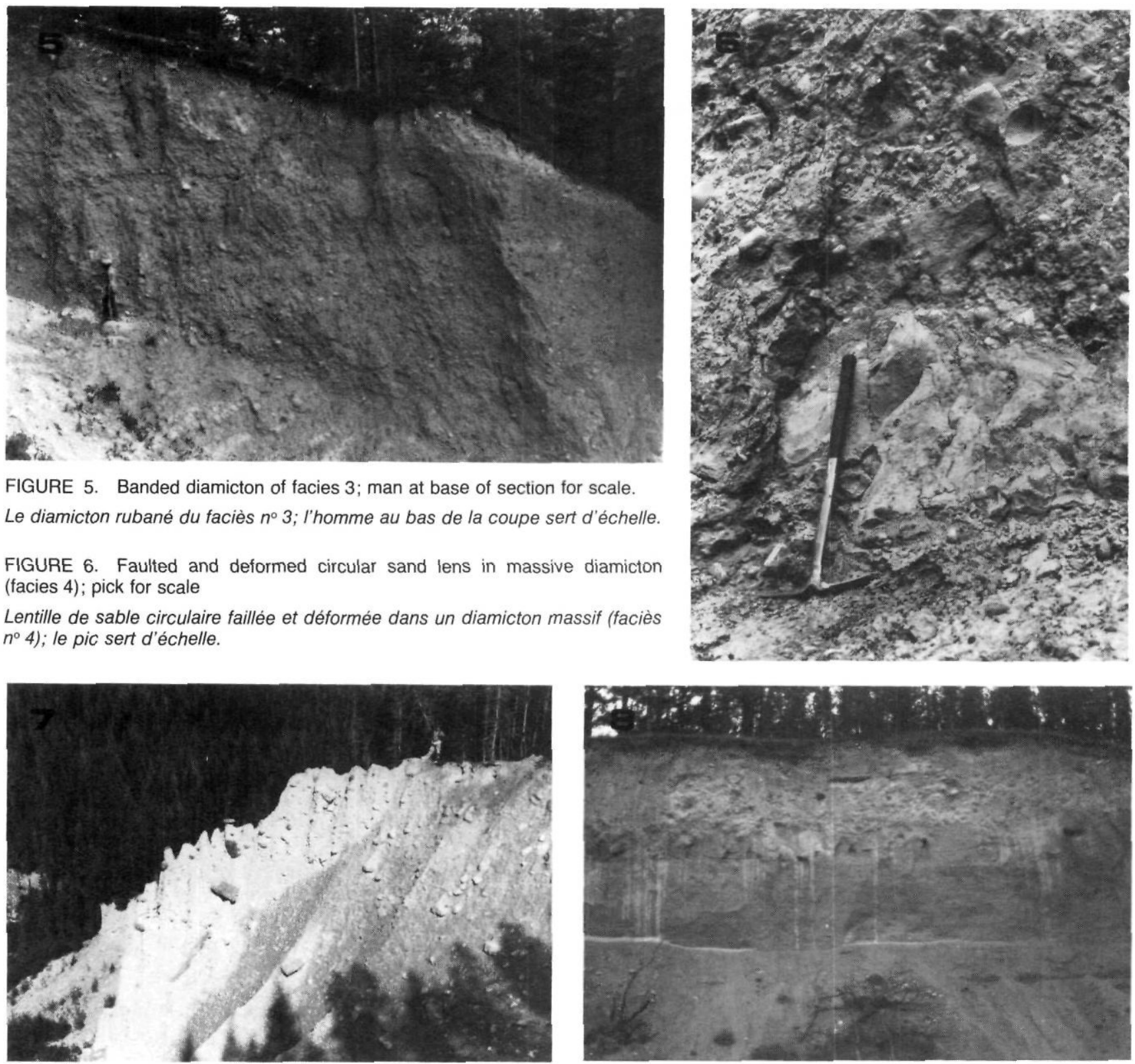

FIGURE 7. Bouldery diamicton with abundant clasts of non-local lithology (facies 5) overlying massive diamicton (facies 1); woman at section top for scale.

Diamicton à blocs comprenant de nombreux fragments de lithologie étrangère au milieu (faciès $n^{\circ} 5$ ) recouvrant un diamicton massif (faciès $n^{\circ} 1$ ); la femme au haut de la coupe sert d'échelle.

FIGURE 8. Massive to moderately stratified diamicton containing trough-shaped sand and gravel lenses (facies 6) overlying a thick sequence of sands and gravels; note scoured lower contact of diamicton. Diamicton is about $5 \mathrm{~m}$ thick.

Diamicton d'aspect massif à moyennement stratifié comprenant des lentilles de sable et gravier en forme de dépression (faciès $n^{\circ} 6$ ) audessus d'une épaisse séquence de sable et gravier; à remarquer le contact inférieur d'affouillement du diamicton (de $5 \mathrm{~m}$ d'épaisseur).

FIGURE 9. Gravelly diamicton interbedded with sands and gravels (facies 7); rock hammer for scale.

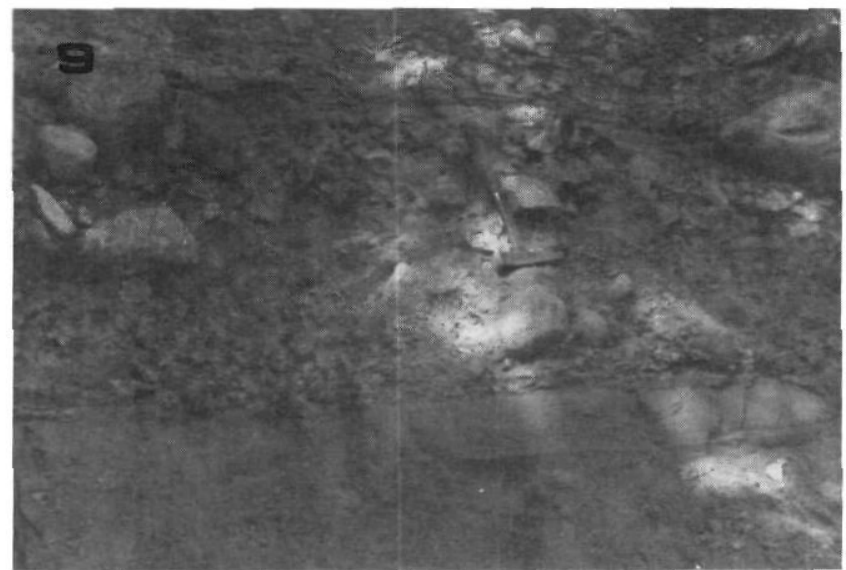

Diamicton gravelleux interstratifié avec des couches de sable et gravier (faciès $n^{\circ} 7$ ); le pic sert d'éche!le. 


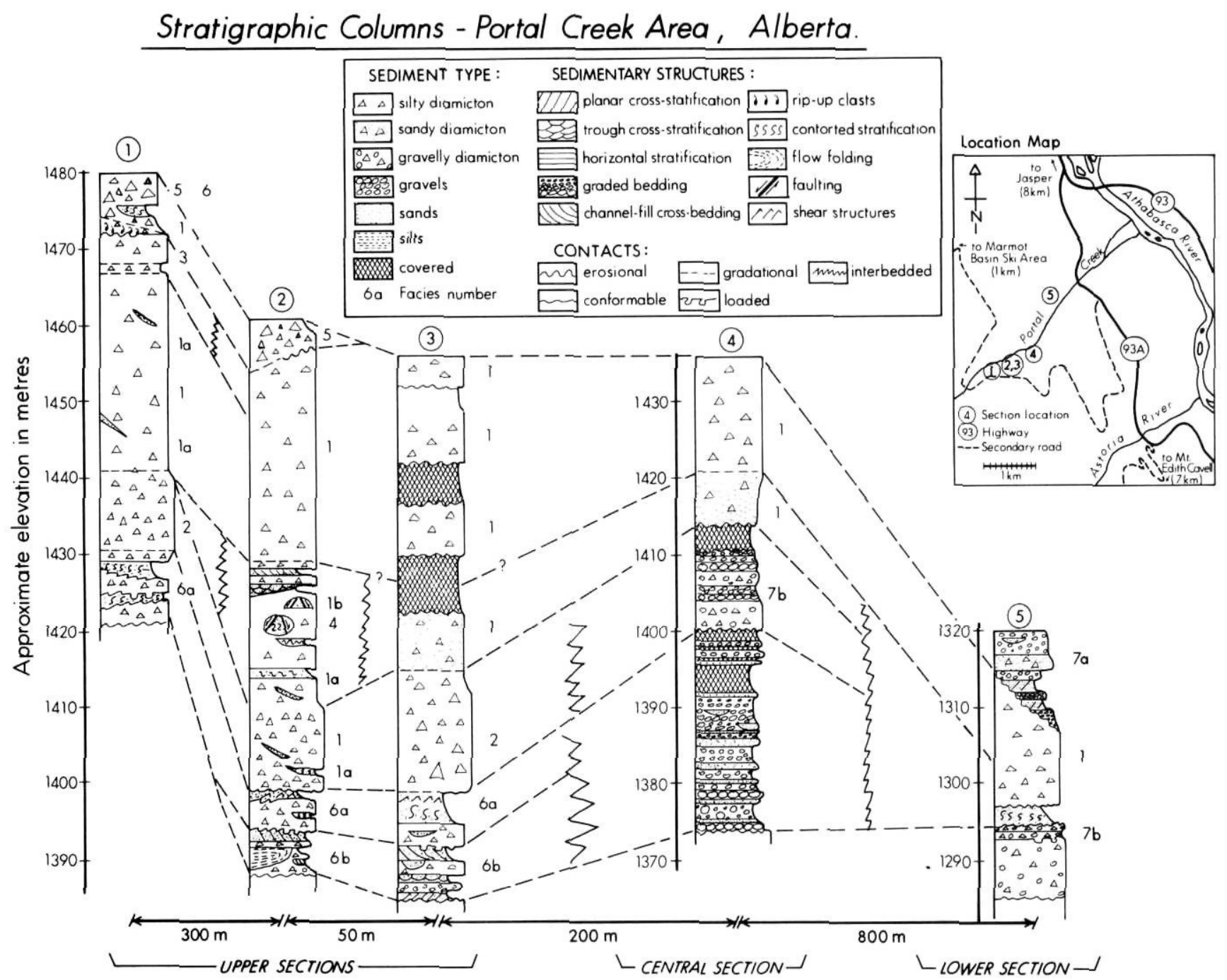

FIGURE 10. Stratigraphic columns of the Portal Creek area; section locations shown on inset map.

and truncated by massive, fine grained, matrix-supported diamicton (facies 1) (Column 5, Fig. 10). A complex deposit of sand, gravel and diamicton (facies 7a) unconformably overlies the diamicton and extends to the surface. All the deposits exposed at this section, except the lowermost diamicton discussed above, have relatively high limestone contents indicating an Athabasca Valley provenance.

\section{CENTRAL PORTAL CREEK AREA}

The base of the central exposure in the Portal Creek area is dominated by gravels (Column 4, Fig. 10). The relatively high limestone content of the gravels $(8 \%)$ indicate at least some input from the Athabasca valley drainage system. The middle of this section is poorly exposed but gravels appear to be interbedded with gravelly diamicton (subfacies 7b) and overlain by massive diamictons of facies 1 . All of the diamicton at this section appears to be derived from the Athabasca valley as indicated by limestone contents varying from 16 $20 \%$.
Stratigraphie de la région de Portal Creek; les sites sont localisés sur le carton.

\section{UPPER PORTAL CREEK AREA}

The lowest exposed sediments in the upper Portal Creek area are massive to moderately stratified diamictons with intercalated sand and gravel lenses (facies 6 ) overlain by a relatively thick, massive, diamicton of facies 1 (Fig. 10). These massive diamictons locally contain abundant, striated, faceted and embedded clasts (facies 2). The lithology of pebbles from these sediments indicates a Portal Creek provenance (Fig. 11, center). Clasts are mainly coarse clastics (60-66 \% sandstone, quartzite, and pebbly conglomerate) and fine clastics (29$39 \%$ shale and siltstone). Limestone does not occur in the interbedded sand, gravel, and diamicton and the average limestone content of the overlying massive diamictons is $2 \%$.

A thick sequence of matrix-supported, silty diamictons (facies 1 and subfacies $1 \mathrm{a}$ and $1 \mathrm{~b}$ ) of Athabasca valley provenance overlie the above sediments (Columns 1-3, Fig. 10). The diamictons are characterized by high total carbonate $(18 \%)$, limestone $(12 \%)$, and fine clastic $(32 \%)$ contents (Fig. 11, center). These diamictons locally contain sand lenses 


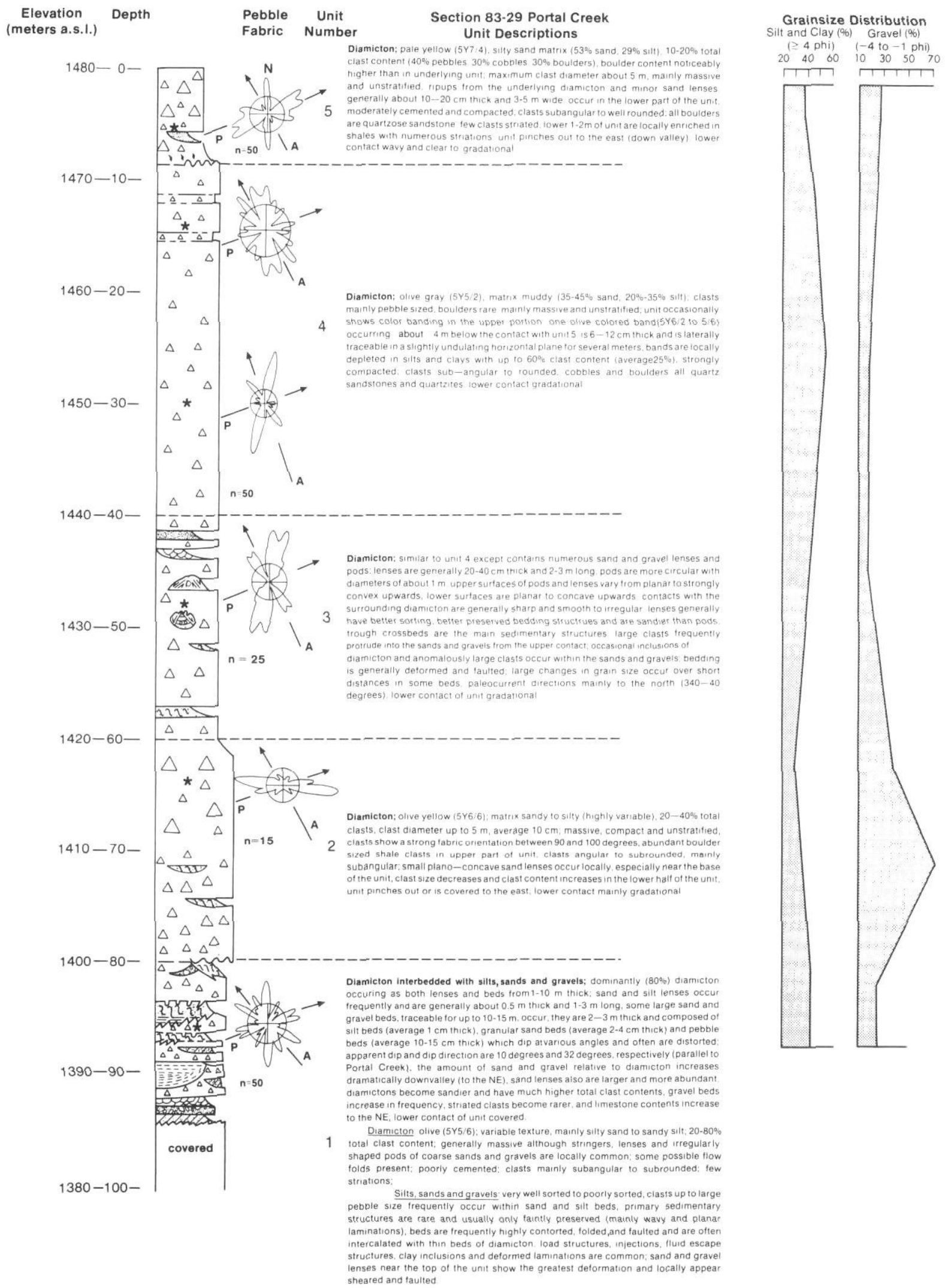

FIGURE 11. Composite stratigraphic column of the upper Portal Creek area, rose diagrams in column 2 represent the two-dimensional orientation of the a-axis of elongated clasts $(\mathrm{N}=$ number of measurements; arrows indicate the orientation of the Athabasca River (A) and Portal Creek (P) valleys); lithostratigraphic units are shown in the third column from the left; textural and lithologic data are given in the center columns; the facies sequence present and environmental interpretations are shown in the last three columns on the right side. 


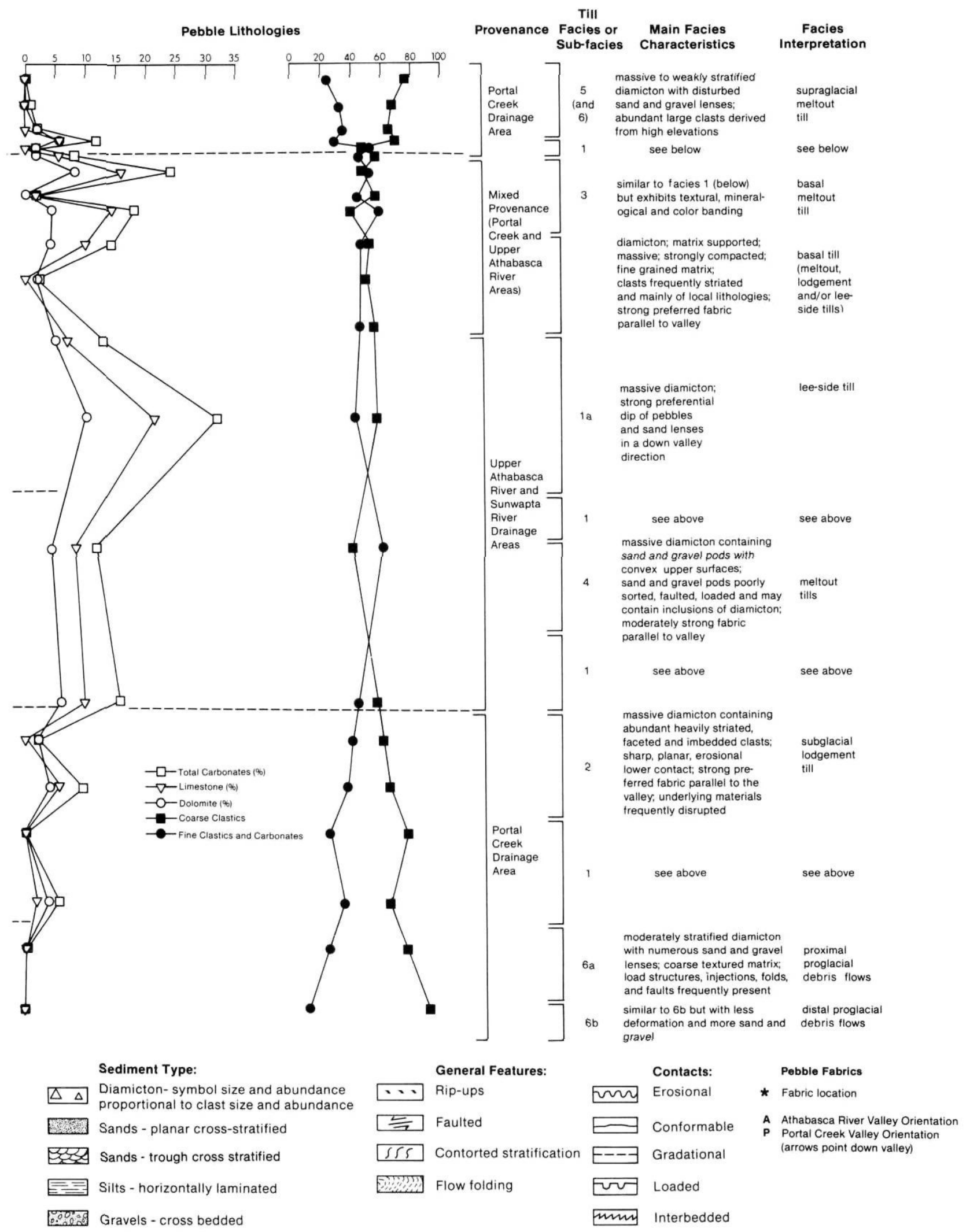

Colonnes stratigraphiques composites de la région du Portal Creek supérieur. Le diagramme circulaire (colonne 2) montre l'orientation bi-dimensionnelle de l'axe en a des fragments allongés $(N=$ le nombre de mesures; les flèches indiquent l'orientation des vallées de la rivière Athabaska $(A)$ et du Portal Creek $(P)$. Les unités li- thostratigraphiques apparaissent dans la troisième colonne à partir de la gauche; les données texturales et lithologiques sont au centre; les trois dernières colonnes de droite représentent la séquence des faciès et les interprétations sur l'environnement. 
near their base (Column 2, Fig. 10). The lenses are circular (facies 4), plano-convex (subfacies 1b) and trough-shaped (subfacies 1a) in cross-section. Most are horizontally oriented but lenses within subfacies 1a exhibit consistent downvalley dips. The diamictons are locally banded (facies 3 ) in their upper part (Column 1, Fig. 10).

The uppermost sediments at Portal Creek (Columns 1 and 2, Fig. 10) are diamictons with a high boulder content and numerous highly disturbed sand and gravel lenses (facies 5 ). Quartzite boulders with diameters of up to $5 \mathrm{~m}$ are common. These sediments are readily distinguished from the underlying deposits by differences in color, texture, and petrology. The abundance of coarse-grained clastic rocks $(70 \%)$ and low percentage of limestone clasts $(2 \%)$ indicate a source area in the Portal Creek watershed rather than the Athabasca valley (Fig. 11, center). These uppermost diamictons thin rapidly and eventually disappear to the northeast (Fig. 10).

\section{SUMMARY}

The lowest exposed sediments in the Portal Creek area are clast-supported diamictons and gravels that extend into the Athabasca valley. They are derived from the Portal Creek valley. Higher up the valley, where Portal Creek first emerges into the Athabasca valley, these sediments have been eroded or are covered by younger deposits. In the lower Portal Creek area (Columns 4 and 5, Fig. 10) these deposits are overlain by sands and gravels derived at least in part from the Athabasca valley. The sands and gravels are in turn overlain by glacial diamictons and associated deposits of Athabasca valley provenance (Columns 4 and 5, Fig. 10). In the northeasternmost exposure (Column 5, Fig. 10), a complex of diamictons and sorted materials overlie a large erosional unconformity.

The lowest exposed sediments in the Upper Portal Creek area are glacial diamictons and associated sand and gravel deposits of Portal Creek provenance (Fig. 11). These are overlain by a thick sequence of diamictons derived mainly from the Athabasca valley. The youngest glacial deposits in the area are diamictons of Portal Creek provenance.

\section{INTERPRETATION OF DEPOSITIONAL ENVIRONMENTS}

\section{LOWER AND CENTRAL PORTAL CREEK AREA}

Gravelly diamicton associated with horizontally stratified, clast-supported, coarse gravels and stratified sands has been commonly observed in alluvial fans (RUST, 1979). The predominance of these facies in the lowest part of the lower Portal Creek valley sections (Column 5, Fig. 10) suggest that they are alluvial fan deposits. The general dip of strata parallel to the Portal Creek valley, the absence of limestone erratics and striated clasts, and the low stratigraphic position of the unit support this interpretation. Lithologic analysis and the dip of the strata suggest a source area to the southwest in the upper Portal Creek basin. In their upper part, these alluvial sediments are interbedded with thin diamictons (facies 7) derived from the Athabasca valley. The interbedding of the diamictons with sands and gravels and their small thickness, restricted lateral extent, and coarse textures indicate that they were deposited in this area as intermittent proglacial flows emanating from Athabasca ice up the valley (Fig. 12a).

Massive diamictons (facies 1) overlie these deposits (Column 5, Fig. 10). The sharp planar contact at the base of these diamictons and compressive deformation (folding and shearing) in the underlying sands suggests that ice overrode the area. The facies 1 diamictons in this area are interpreted as basal tills based on the abundance of striated clasts of local lithology, fine matrix textures, and a strong unimodal pebble fabric. These diamictons are unconformably overlain by glaciofluvial sand and gravel deposits. The unconformity is probably the result of fluvial erosion that occurred in immediate post glacial times as meltwaters flowed to the Athabasca valley center. The amount of erosion is not known but ten or more meters of fluvial sediment overlie the till (Column 5, Fig. 10). Outwash deposits overlying the unconformity are interbedded with sandy diamictons (facies 7), interpreted as proglacial flow tills deposited during retreat of Athabasca ice.

Athabasca valley ice must have initially been restricted to the center of its valley because thick basal tills in that area (Column 5, Fig. 10) grade laterally into outwash sands and gravels in the central Portal Creek valley (column 4, Fig. 10). The sands and gravels were likely deposited in a lateral; icemarginal position (Fig. 12b). This interpretation is supported by the presence of diamictons of facies 7 , interpreted as lateral, ice-marginal debris flow deposits, interbedded with the sands and gravels in their upper part (Column 4, Fig. 10).

All of the glacial deposits in the lower Portal Creek area are of Athabasca provenance. Glacial diamictons of facies 6 (massive to moderately stratified diamicton containing numerous trough-shaped sand and gravel lenses) of Portal Creek provenance increase in abundance upvalley (to the SW) and dominate the lowest exposed sediments in that area (Columns 1-3, Fig. 10). Thus, the lateral facies change from Portal Creek till in the southwest to sands and gravels and finally to Athabasca till in the northeast suggests that the sands and gravels were deposited in an ice free environment between Athabasca and Portal Creek ice (Fig. 12b). The dominance of facies 1 diamicton, interpreted as basal till of Athabasca provenance, in the upper parts of the central and lower Portal Creek sections (Columns 4 and 5, Fig. 10), suggests that Athabasca ice eventually overrode the entire area (Fig. 12C).

\section{UPPER PORTAL CREEK AREA}

In the southwestern part of the Portal Creek area diamictons of facies 6 dominate the lower part of the sections (Columns 13, Fig. 10). They are interpreted as mass movements emanating from a glacier terminus. This interpretation is based partially on their interbedded nature with channelled, sheeted, and rilled sand and gravel deposits. The presence of flow folds, abundant load structures, and clasts that deform, and appear to have 'settled' into, underlying beds supports this interpretation. Subfacies $6 \mathrm{~b}$ grades vertically upwards into subfacies $6 a$ at several localities. A similar facies change occurs laterally from the northeast to the southwest at the same stratigraphic level with subfacies $6 a$ dominating in the 


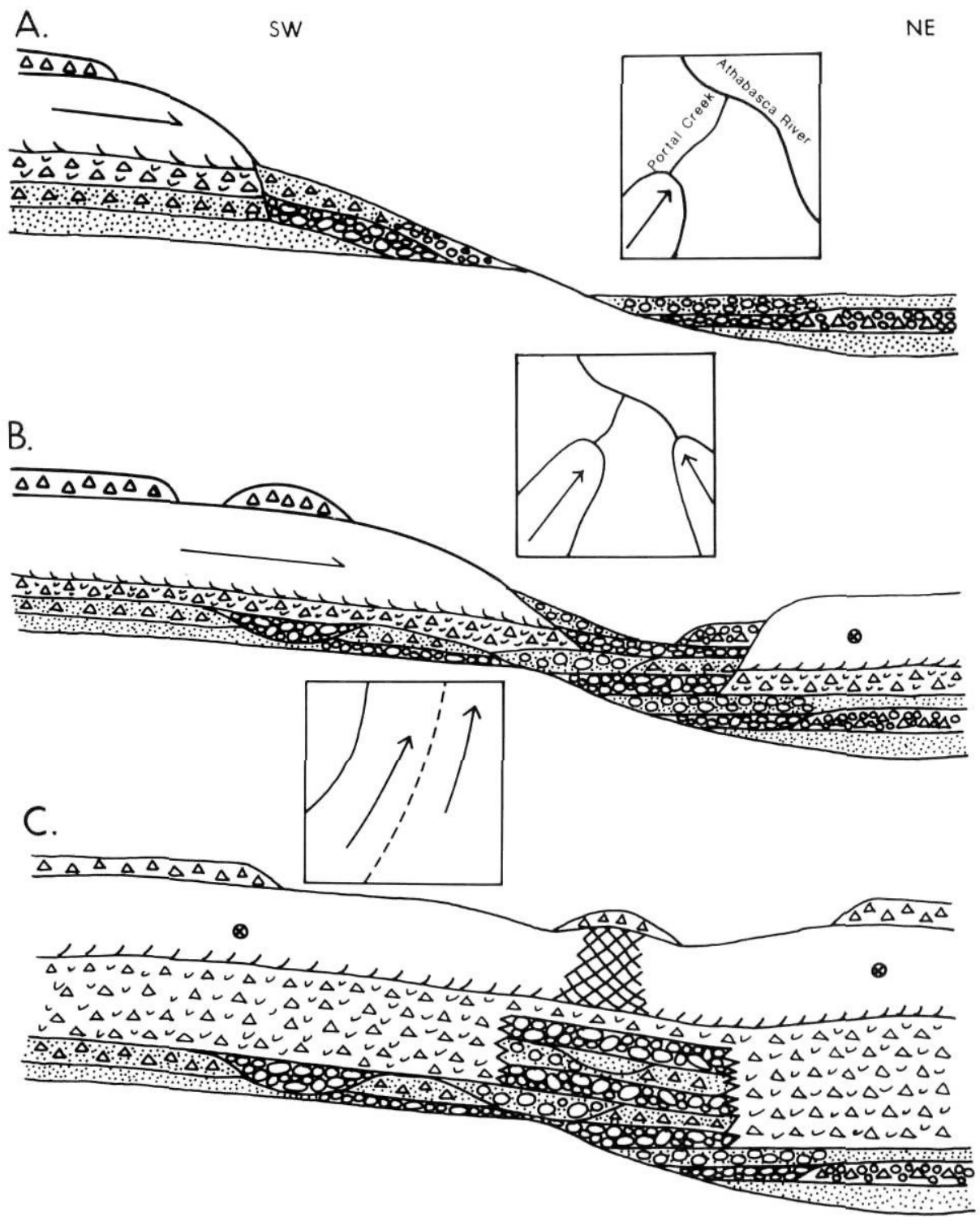

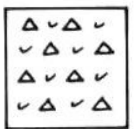

Facies 1 \& 2

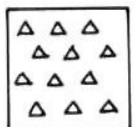

Facies 5

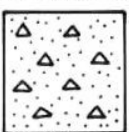

Facies 6

$\Delta \because \therefore \Delta$

$\therefore \therefore$

10

Facies 7

00

0.0

0.0

Sands \& gravels
FIGURE 12. Schematic diagram representing early glacial deposition in the Portal Creek area: a) deposition of proglacial flow tills in front of the advancing Portal Creek and Athabasca valley glaciers; b) deposition of glaciofluvial gravels and lateral till flows between the two glaciers; c) deposition of basal tills throughout the area and development of a medial debris-rich zone in the ice (cross-hatched area); see location map on Figure 10 for location and scale of inset maps.

southwest (Columns 1-3, Fig. 10). This vertically upwards and laterally southwestwards transition from subfacies $6 b$ to subfacies 6 a (interpreted, respectively, as distal and proximal proglacial debris flows) suggests movement of ice into the area from the southwest down the Portal Creek valley (Fig. 12a). The relative abundance of diamicton, poor sorting of associated sands and gravels, and abundance of faults, folds and shear structures in subfacies 6a (compared to subfacies $6 b$ ) is believed to be the result of close proximity to and subsequent overriding by Portal Creek ice. This interpretation is supported by an increase in sand and gravel deposits of fluvial origin towards more distal locations to the
Schéma représentant la mise en place des dépôts anaglaciaires dans la région de Portal Creek; a) mise en place des moraines d'écoulement proglaciaire en avant des glaciers de vallée d'Athabaska et de Portal Creek en progression; b) dépôt des graviers fluvio-glaciaires et des moraines latérales entre les deux glaciers; c) dépôt des moraines de fond partout dans la région et développement d'une zone médiane de glace riche en débris (voir la fig. 10 pour la localisation et l'échelle des cartons).

northeast, as well as by the low limestone content of the till indicating a Portal Creek provenance. In addition, the proximal deposits of subfacies $6 a$ are everywhere overlain by massive diamictons of facies 1 and 2, interpreted as basal tills deposited by the advancing Portal Creek glacier.

The diamictons of facies 2 , interpreted as lodgement tills due to the presence of abundant striated, faceted, and embedded clasts, grade vertically upwards and laterally into those of facies 1 which dominates most of the upper Portal Creek sections (Columns 1-3, Fig. 10). The intimate association of these two facies suggests that, at this locality, they are of the same origin (Fig. 12). 
Lithological and pebble fabric analysis indicate that most of the diamicton in the central part of the upper Portal Creek sections is of Athabasca valley provenance and was probably deposited by ice that flowed at some angle across the Portal Creek valley (Fig. 12c). The movement of Athabasca ice across the valley created by Portal Creek would have resulted in eventual infilling of the valley by glacial debris. GARNES and BERGERSEN (1977) found large accumulations of basal till in similar topographic situations. Till deposited in analogous environments has been termed 'lee-side till' by HALDORSEN (1982).

An analysis of the vertical facies sequence within the central portions of the sections shows that facies 1 is complexly associated with subfacies 1 a (columns 1 and 2, Fig. 10). Sand lenses and elongated pebbles within subfacies 1 a show a preferred downvalley plunge parallel to the Athabasca valley. Subfacies $1 \mathrm{a}$ is interpreted as a lee-side till. Its common occurrence and association with facies 1 suggests that most of the diamicton in the central part of the upper Portal Creek sections accumulated at the base of the Athabasca valley glacier in a lee-side locality (i.e. in the bedrock depression created by Portal Creek; Fig. 13). The preferred plunge of sand lenses and elongated clasts is the result of deposition of material along the slopes of the preexisting Portal Creek valley by overriding Athabasca ice. A decrease in the magnitude of the preferred plunge upsection, supports this interpretation since the slope of the valley walls would decrease as the valley was infilled.

The actual mechanism of deposition of subfacies $1 \mathrm{a}$ and the associated diamictons in this area may have been by lodgement, melt-out, or flow into basal cavities. If a subglacial cavity formed under this glacier in the bedrock depression created by the Portal Creek valley, it probably developed at an early stage when infilling of the latter was at a minimum and the valley slope was relatively steep (Fig. 13a). Thus, the depositional mechanism may initially have been the flowage of debris into subglacial cavities in a manner similar to that observed by BOULTON $(1970,1971)$ at the base of modern Spitsbergen glaciers. The cavities studied by BOULTON (1970) were about five meters in width but much larger cavities could exist depending on the shape and geometry of the pre-existing topographic surface and on the flow rate and inherent plasticity of the ice. A cavity large enough to allow for the accumulation of $10-20 \mathrm{~m}$ of debris may have been tens or even hundreds of meters in diameter. The abundance of sand lenses in the lower part of these diamictons and their absence in stratigraphically higher deposits (Fig. 11), further suggests the initial presence of a subglacial cavity. Subglacial stream channels would be expected in an open cavity system but continued infilling of the cavity with subglacial debris would eventually have allowed the overriding glacier to come into contact with, and conform to, the valley-fill surface (Fig. 13b).

A melt-out origin for some of the diamicton in the upper Portal Creek sections is suggested by the presence of facies $1 \mathrm{~b}$, 3 , and 4 (Columns 1 and 2, Fig. 10). Facies 4 diamictons are characterized by the presence of circular sand and gravel lenses. The convex upper surface of these sand and gravel bodies suggests that they formed englacially. The presence of numerous high angle normal faults on their margins indicates collapse during melt-out. Banded diamictons (facies 3 ) are interpreted as basal melt-out tills based on the presence of characteristics similar to melt-out tills described from modern environments (eg. LAWSON, 1979). A major diagnostic characteristic is the presence of distinct bands or layers within the diamicton, of variable texture, composition, and/or color, that may be draped over large clasts (LAWSON, 1981). Diamictons of subfacies $1 \mathrm{~b}$ are also interpreted as basal melt-out tills based largely on the presence of plano-convex sand and gravel lenses similar to those discussed by SHAW (1982). In addition, massive till of facies 1 is complexly associated with facies 1b, 3 and 4 (Columns 1 and 2, Fig. 10) and may also have been deposited by melt-out.
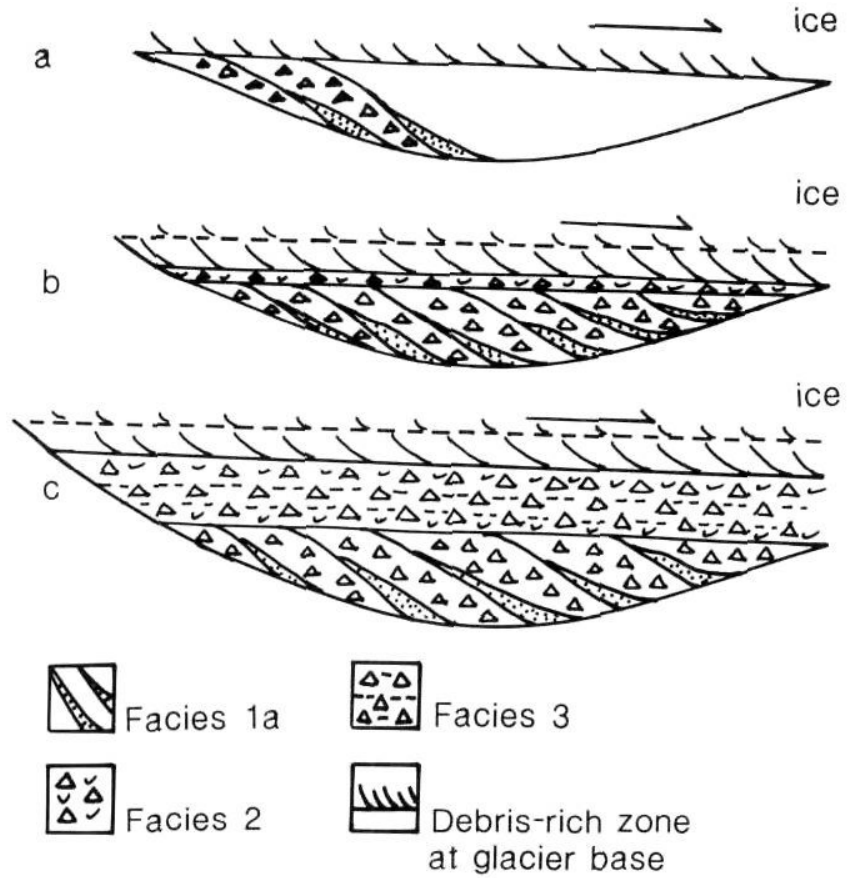

FIGURE 13. Schematic diagram representing the deposition of leeside till during full glacial times: a) deposition of flow tills and small sand and gravel deposits in subglacial cavities; b) complete infilling of subglacial cavities and deposition of lodgement till; incipient development of a shear zone within the glacier; c) formation of melt-out till from layers of debris-rich ice stranded beneath active ice; deposition of lodgement till at the base of active ice; development of new shear zones at progressively higher positions within the glacier; no scale is given due to the hypothetical nature of the cross sections; the actual configuration of the glacier base and underlying surface are not known but are assumed to be much more irregular than shown.

Schéma représentant la mise en place de la moraine proximale au pléniglaciaire: a) mise en place de la moraine et de petits dépôts de sable et gravier dans des dépressions sous-glaciaires; b) remplissage des cavités sous-glaciaires et mise en place de la moraine de fond; amorce de développement d'une zone de cisaillement à l'intérieur même du glacier; c) mise en place de moraines provenant de la fonte des couches de glace riche en débris abandonnée sous la glace active; mise en place de la moraine de fond à la base de la glace active; développement graduel de nouvelles zones de cisaillement dans les parties plus élevées du glacier. On ne fournit aucune échelle en raison du caractère hypothétique des coupes. La forme véritable de la base du glacier et de la surface sous-jacente n'est pas connue; elle est probablement beaucoup plus irrégulière. 
A melt-out origin for these diamictons would only be possible if a sufficient thickness or concentration of debris-rich ice was present to account for their large cumulative thickness. Debris concentrations of up to $75 \%$ have been reported for some modern temperate glaciers (BOULTON, 1968, 1975; LAWSON, 1979) but generally such debris-rich bands are in the order of centimeters or meters in thickness and not tens of meters. However, thicker accumulations of debris would be possible if the basal shear zone of a glacier overriding a depression gradually moved up into the ice thereby stranding a successive series of debris-rich blocks beneath the glacier (Fig. 13). Thus the thickness of the accumulating melt-out till would be limited primarily by the depth of the depression.

In this interpretation, debris deposited along the active shear zone by lodgement processes would be intimately associated with till melting out from underlying debris-rich layers. in addition, shear zones may have become reactivated after some melt-out had already occurred or new shear zones may have developed in subglacial debris previously deposited by melt-out mechanisms. Consequently, a gradation between lodgement and melt-out till would be expected. The diamictons in the central part of the upper Portal Creek sections exhibit characteristics that, depending on the area, are typical of either lodgement till, melt-out till (either basal or englacial), or some intermediate variety of the two types. A similar gradation between genetic varieties of till was observed in leeside localities by HALDORSEN (1982).

The lower contact of the uppermost stratigraphic unit in the upper Portal Creek area varies from gradational to sharp and wavy (Columns 1 and 2, Fig. 10). The nature of this contact, together with the increase in fine-grained clastic pebbles and the presence of rip-up clasts in the lower portion of the surface unit, indicates that the contact is, at least locally, an erosional unconformity.

Three facies can be recognized in the surface unit in the upper Portal Creek area (Columns 1 and 2, Fig. 10). A massive diamicton (facies 1) occurs locally in the lower part of the unit. The abundance of striated clasts indicates a basal origin but the dominance of shale (Fig. 11) may in part be the result of incorporation of sediment from the underlying shale rich deposits. The low limestone content at the base of the surface unit, however, indicates that these basally derived sediments originated in the Portal Creek valley and not in the Athabasca valley as is the case for most of the underlying sediments.

The upper portion of the surface unit (Fig. 8) is largely composed of diamictons of facies 5 (bouldery diamicton with numerous, highly disturbed, sand and gravel lenses), which grade laterally and vertically into facies 6 (massive to moderately stratified diamicton containing abundant, trough-shaped sand and gravel lenses). Facies 5 diamictons are interpreted as supraglacial flow tills based on the abundance of large clasts, rarity of clast striations, coarse matrix textures, dominance of lithologies from formations outcropping at high elevations, and the presence of faulted and disturbed sand and gravel lenses. Facies 6 diamictons are interpreted as proglacial till flows.

\section{STRATIGRAPHIC IMPLICATIONS}

The environmental analysis of the facies present in the Portal Creek area has several stratigraphic implications. Lithologic studies of clasts in tills suggest that the area was influenced at different times by ice originating in separate valleys. The lithologic variations are most complex in the upper Portal Creek area. A composite stratigraphic column of the upper Portal Creek area is provided in Figure 11. A traditional stratigraphic grouping of the deposits, based on textural and lithologic analysis of the tills, is provided on the left-hand side of Figure 11. Five stratigraphic units can be recognized. These in turn can be grouped into three sedimentary packages of distinct provenance as shown by the horizontal dashed lines in the center of Figure 11. The lowest exposed sediments in this area (Units 1 and 2, Fig. 11) are tills and associated sand and gravel deposits of Portal Creek provenance. These are overlain by a thick sequence of tills derived mainly from the Athabasca valley (Units 3 and 4 , Fig. 11). The youngest glacial deposits in the area are tills also of Portal Creek provenance (Unit 5, Fig. 11). A more detailed analysis of the deposits, based on the sedimentary facies present, is given on the right-hand side of Figure 11. Environmental interpretations of the facies are given in the last column.

The following discussion evaluates the time-stratigraphic significance of the three main sedimentary packages in the Portal Creek area, by applying information provided by the facies analysis. Specifically, the change from deposits of Portal Creek provenance to those of Athabasca valley provenance at the unit 2/3 contact and the reverse transition at the unit 4/ 5 contact (Fig. 11), are evaluated. Genetic interpretations of the associated tills are used to determine whether or not the contacts represent significant time-hiatuses between separate glacial episodes.

An overall analysis of the interpretation of the vertical distribution of facies shown on Figure 11 reveals that proglacial deposits are overlain by a thick basal till sequence which is in turn overlain by a relatively thin supraglacial till. The expected progression from proglacial to basal to supraglacial deposits suggests that the entire sequence was deposited during one glacial event. However, a more detailed analysis indicates that this is probably not the case.

The presence of Portal Creek tills at the base of the sections (Units 1 and 2, Fig. 11) indicates the movement of Portal Creek ice into the area. The overlying till (unit 3, Fig. 11) is largely of Athabasca valley provenance indicating the subsequent movement of Athabasca ice into the area. A transition zone between units 2 and 3 is shown by a gradual upward increase in the limestone and total carbonate content and by a decrease in the coarse to fine clastic pebble ratio. From stratigraphic evidence alone it cannot be determined if this transition from till of Portal Creek provenance to till of Athabasca valley provenance is a result of two separate glacial episodes or merely due to increasing dominance of advancing Athabasca ice resulting in confinement of Portal Creek ice to the southwestern side of the valley. Tills in the transition zone are primarily interpreted as basal tills (facies 1 and 2). The absence 
of any facies containing sorted materials indicative of icemarginal deposits suggests that ice did not retreat from the area during the period of deposition of units 2 and 3 . Consequently, the gradual increase in the limestone content of tills in units 2 and 3 is probably the result of the gradual lateral expansion of the Athabasca valley glacier. This is supported by the presence of facies 1 diamictons, interpreted as basal Athabasca valley tills, at much lower stratigraphic levels to the northeast than further to the southwest (Columns 4 and 5, Fig. 10).

In addition, diamictons of facies 7 , interpreted as lateral ice-marginal debris flows, grade vertically upwards and laterally northeastwards into basal tills (facies 1 ) of Athabasca valley origin (Columns 4 and 5, Fig. 10). This suggests that there was active ice depositing basal tills in the valley center while debris was flowing off the SW margin of the ice. Later expansion of the active ice resulted in the deposition of basal tills throughout the area. The vertical sequence from fluvial gravels to gravels interbedded with diamictons of facies 7 to glacial diamicton of facies 1 is also consistent with the above interpretation.

Fluctuations in the carbonate content of tills in the upper Portal Creek area (units 3 and 4, Fig. 11) suggest a mixed Portal Creek and Athabasca provenance. This 'mixing' may have been the result of changes in the relative lateral confinement and expansion of the two glaciers. This interpretation is supported by pebble fabric diagrams for units 3 and 4 (Fig. 11) which exhibit principal orientations intermediate between the orientations of the Athabasca and Portal Creek valleys. This suggests the influence of ice from both sources. A similar situation involving two confluent glaciers in the Rocky Mountain Trench has been described by BROSTER and DREIMANIS (1981).

The uppermost unit at Portal Creek (unit 5, Fig. 11) is of Portal Creek provenance as indicated by the low limestone content and relatively high proportion of coarse clastic pebbles, particularly quartzitic sandstones. The difference in provenance between unit 5 and underlying units suggests that a separate glacial episode (a readvance or significant stillstand) occurred. The following lines of evidence all suggest that this was the case, although none of the arguments presented are conclusive in themselves:

1. The presence of deposits interpreted as both basal and supraglacial tills (representing a complete depositional cycle) in unit 5 provides some of the strongest evidence that the unit was deposited during a different episode than the underlying units. However, supraglacial tills are dominant and basal tills are only intermittently present and difficult to observe in section. This abundance of supraglacial till compared to deposits in the Athabasca valley can be explained by differences in source valley geometry. The narrow steep walls of the Portal Creek valley are much more conducive to rock falls and slides than the broad, gentle sided, Athabasca valley. The intermittent occurrences of the basal deposits can be accounted for by a variety of mechanisms. For example, advancing glaciers do not always deposit a continuous sheet of till at their bases, or, if they do, erosion by subglacial streams may result in local removal of basal sediment.
2. The lithologic change between units 4 and 5 indicates a different provenance for the two units. Lithologic differences, however, may be explained by differences in the genesis of the deposits dominating each of the two units. During the formation of supraglacial deposits, for example, landslides on to the ice surface may result in a deposit with significant lithologic differences from other till types (such as basal tills). Still, the lithology of pebbles within units 4 and 5 are generally consistent even across facies boundaries (Fig. 11) suggesting that the lithologic differences between the units are the result of different provenances and not facies changes. Unfortunately, unit 5 is dominated by one main sediment association (facies 5 and 6), and the restricted occurrence of facies 1 prohibited detailed lithologic comparisons with facies 5 and 6 .

3. The erosional unconformity and the presence of a basal till at the base of unit 5, albeit poorly represented, suggests that erosion along the contact was carried out by active ice. The absence of a gravel lag overlying the contact indicates that erosion by meltwater from the potentially large volume of ice between supraglacial sediments and subglacial or basal sediments did not create the unconformity.

4. An analysis of pebble fabric rose diagrams for units 4 and 5 lends support to the 'two event' theory. The preferred orientation of pebbles in unit 5 is clearly parallel to the orientation of the Portal Creek valley (Fig. 11). Unit 4 pebble fabrics more nearly approximate the orientation of the Athabasca River valley (Fig. 11). Although the strength of the preferred orientations are not high, the differences between the rose diagrams for the two units suggest different ice sources.

5. In the Astoria River valley (Fig. 2), just south of the Portal Creek valley, the presence of stratified materials between two major tills similar in nature and stratigraphic position to the upper two till units at Portal Creek also indicates that a separate glacial event did occur in the area.

6. The presence of relatively well developed lateral moraines in the upper reaches of the Portal Creek and Astoria River valleys, suggests that a glacial advance of significantly younger age than that represented by most of the deposits at Portal Creek, may have occurred. Extrapolation of these moraines indicates that the southwestern-most Portal Creek sections (Columns 1 and 2, Fig. 10) lie near the termination of this event. Unit 5 (Fig. 11) may therefore represent the deposits of a terminal moraine. Such moraines, formed by valley glaciers and derived largely from supraglacial debris, have been termed 'lateral-frontal dump moraines' (BOULTON and EYLES, 1979). In such a morainal environment, proglacial till flows on and near the snout of the glacier would be expected and deposits similar to facies 5 and 6 would be common.

The regional surface morphology in the Portal Creek area is dominated by gentle flutings that enhance the linear topography produced by the strike of bedrock ridges. The thin supraglacial till cover has little or no surface expression. No well developed terminal moraine is apparent although a low, broad ridge lies across the mouth of the Portal Creek valley. The ridge may represent the terminus of the advance discussed above or it may have formed by colluvial processes that tend to obscure most glacial features in the region. The upper few 
meters of the Portal Creek sections have experienced some gravity movements, but the amount of disruption is probably minor as indicated by the presence of undisturbed sand lenses.

\section{GLACIAL HISTORY OF PORTAL CREEK AREA}

From the stratigraphic and geomorphic evidence given in this paper and from the above facies analysis, the glacial history of the Portal Creek area can be summarized as follows.

Glacial ice moving down the Athabasca valley was initially confined to the valley center (Fig. 12). Proglacial flow tills were deposited over pre-existing alluvial sediments originating from the tributary Portal Creek valley. Portal Creek ice spilled out into the Athabasca valley before the latter was fully occupied by Athabasca ice (Fig. 12a). Outwash gravels were deposited in a kame-like feature in the intervening area between the two glaciers by meltwater streams emanating from both ice tongues (Fig. 12b). Distal debris-flows were deposited with the outwash sediments in front of the advancing Portal Creek glacier. These were successively overlain by more proximal proglacial deposits and eventually by lodgement tills deposited by overriding Portal Creek ice. Further to the northeast, the glaciofluvial sands and gravels deposited along the margins of the Athabasca ice were gradually succeeded by lateral icemarginal flow tills. Further expansion of Athabasca ice resulted in coalescence with Portal Creek ice and the deposition of basal tills throughout the region (Fig. 12c). The overriding ice deformed and sheared the underlying deposits and created a sharp, erosional unconformity in most areas.

Eventually, the more dominant Athabasca valley glacier resulted in confinement of Portal Creek ice to the southwestern side of the Athabasca valley. The northwest-southeast trending margin between these two glaciers appears to have fluctuated, probably as a result of variations in the rate and volume of ice flow down each valley. A thick sequence of lee-side till accumulated in the bedrock depression created by the Portal Creek valley as a result of deposition at the base of these confluent glaciers as they moved transversely across the depression (Fig. 13). Subglacial flow, lodgement, and meltout tills were the main types of till deposited. The Athabasca valley glacier dominated for most of the depositional period but till of mixed Portal Creek and Athabasca valley provenance was also deposited, especially in the latter stages of glaciation.

The thick sequence of tills deposited in the lower Portal Creek valley were partially eroded following deglaciation. Erosion was concentrated in the valley center where meltwaters were channelled. Proglacial debris flows were locally deposited with outwash deposits during ice retreat.

In the upper Portal Creek valley, erosion of the underlying tills appears to have taken place by ice moving out of Portal Creek. It is not known if Portal Creek ice merely continued to flow after the Athabasca valley glacier had retreated from the area, or if the Portal Creek glacier readvanced at some later time. Based on sedimentologic data, facies associations, geomorphic evidence from lateral moraines in the region and on preliminary stratigraphic information from the Astoria River valley, it appears that a readvance or major late-glacial stillstand occurred. Glacial ice during this event appears to have flowed down the Portal Creek valley and terminated near its junction with the Athabasca valley. The uppermost unit exposed in the Portal Creek area may represent a thin basal till overlain by a relatively thick supraglacial/proglacial till sequence deposited at the terminus of this glacier. The Portal Creek glacier had a more extensive supraglacial cover than Athabasca ice and, consequently, the deposits left during this late stage event were mainly supraglacially derived. A small terminal dump moraine may have developed at the margin of the Portal Creek glacier during this final event.

\section{GLACIAL CHRONOLOGY}

The bulk of the glacial deposits studied are believed to be Late Wisconsinan in age. This assumption is based on two radiocarbon dates from materials collected during the course of this study. A finite date of $29,100 \pm 560{ }^{14} \mathrm{C}$ years BP (GSC-3792) was obtained on wood found in outwash sediments underlying a surface till, in the Jasper townsite area (Fig. 1). The wood pieces were angular and fragile suggesting that they had not been reworked from older deposits and that the overlying till is Late Wisconsinan in age. In the Pocahontas area (Fig. 1), gastropods were collected from a surface unit of glaciolacustrine silts and clays presumably deposited at the margins of a retreating glacier. They were dated at $11,900 \pm 120{ }^{14} \mathrm{C}$ years BP (GSC-3885) thus providing a minimum date for deglaciation of that area. No prominent geomorphic breaks occur between Pocahontas, Jasper townsite and Portal Creek suggesting that all the surficial glacial deposits in the major valleys in the Jasper region north of the Portal Creek area were deposited in the period effectively bracketed by the above two dates.

Due to the presence of a moraine system which probably terminates in the vicinity of the Portal Creek sections, and for other reasons outlined in the previous section, it is believed that the surface unit at Portal Creek (unit 5) was deposited in a separate glacial event of relatively limited extent. Since no advance of this magnitude has occurred in the last 10,000 years (LUCKMAN and OSBORN, 1979; KEARNEY and LUCKMAN, 1981) this event must also be Late Wisconsinan in age.

In summary, the Portal Creek stratigraphic record represents two Late Wisconsinan advances. The earlier advance (represented by units $1-4$ at Portal Creek and by surface tills further north) extended beyond the study area. The later advance was restricted to high tributary valleys such as the Portal Creek valley. Ice moving down the Portal Creek valley probably terminated in the vicinity of the upper Portal Creek sections (Fig. 11) where it deposited unit 5. The extent of this later advance in other valleys is presently under investigation.

\section{CONCLUSIONS}

Stratigraphic and provenance studies in the Portal Creek region reveal three major sediment packages of distinct provenance indicating that three separate glacial events may have occurred. However, a detailed facies analysis of the deposits shows that the oldest two groups of sediment probably were deposited during the same episode. Changes in till 
provenance are believed to be the result of fluctuations in the dominance of two confluent glaciers originating in different valleys. The facies analysis supports the stratigraphic evidence that the third sedimentary package was deposited in a distinct glacial episode. The erosional unconformity between the second and third sedimentary packages (units 3 and 4 and unit 5 , Fig. 11) that was probably formed by overriding ice; the presence of both basal and supraglacial till types above the contact; differences in pebble fabric and lithology; the presence of intervening stratified materials in stratigraphically equivalent deposits in the Astoria River valley; and the presence of weakly developed lateral moraines (the extrapolation of which terminate in the vicinity of the Portal Creek sections); all support the interpretation that the upper-most unit at Portal Creek (unit 5, Fig. 11) was deposited during a separate glacial event (a readvance or significant still-stand). More research in adjacent valleys is required to assess the regional significance of this event.

\section{ACKNOWLEDGEMENTS}

The authors would like to thank Parks Canada for permission to conduct their research in Jasper National Park. Funding for this study was provided by the Boreal Institute and by a NSERC grant to Dr. N. W. Rutter. The authors also wish to thank Dr. David N. Proudfoot and Dr. Lionel Jackson for their comments on the manuscript.

\section{REFERENCES}

BOSTOCK, H. S. (1970): Physiographic subdivisions of Canada, In Douglas, R. J. W. (ed.), Geology and Economic Minerals of Canada, Geological Survey of Canada, Economic Geology Report No. 1, p. 10-30.

BOULTON, G. S. (1968): Flow tills and related deposits on some Vestspitzbergen glaciers, Journal of Glaciology, Vol. VII, No. 51, p. $391-412$.

(1970): On the origin and transport of englacial debris in Svalbard glaciers, Journal of Glaciology, Vol. IX, No. 56, p. 213229.

- (1971): Till genesis and fabric in Svalbard, In Goldthwait, R. P. (ed.), Till: a Symposium, Ohio State University Press, Columbus, Ohio, p. 41-72.

(1975): Processes and patterns of subglacial sedimentaion, a theoretical approach, in Wright, H. E. and Mosley, J. T. (ed), Ice Ages: Ancient and Modern, Seel House Press, Liverpool, p. 7-43.

(1976): A genetic classification of tills and criteria for distinguishing tills of different origin, in Stankowski, W. (ed.), Till - its genesis and diagenesis, Uniwersytet Adama Mickiewicza, Seria Geographia No. 12, Poznan, p. 65-80.

BOULTON, G. S., and EYLES, N. (1979); Sedimentation by valley glaciers, a model and genetic classification, in Schultcher, J. M. (ed.), Moraines and Varves, Balkema Press, Rotterdam, p. 1125.
CAMPBELL, R. B., compiler, (1971): Geological map of part of the southeastern Canadian Cordillera, in Wheelor, J. O. (ed.), Structural style of the southern Canadian Cordillera. International Geological Congress, twenty-fourth session, field excursion X01-AO1, map, scale 1: 750,000.

DREIMANIS, A. (1976): Tills - their origin and properties, in Legget, R. E. (ed.), Glacial till an interdisciplinary study, Royal Society of Canada, Ottawa, Special Publication No. 12, p. 11-50.

(1982): Genetic classification of tills and criteria for their differentiation, and definitions of glacigenic terms, in Schlultcher, J. M. (ed.), INQUA Commission on the genesis and lithoiogy of Quaternary deposits, Work Group 1 - Progress report on activities 1977-1982, p. 1-20.

GARNES, K. and BERGERSEN, O. F. (1977): Distribution and genesis of tills in central south Norway, Boreas, Vol. VI, p. 135-147.

HALDORSEN, S. (1982): The genesis of tills from Astadalen, southeastern Norway, Norsk Geologisk Tidsskrift. Vol. 62, No. 1, p. $17-$ 38.

KEARNEY, M. S., and LUCKMAN, B. H. (1981): Evidence for Late Wisconsin - early Holocene climatic/vegetational change in Jasper National Park, Alberta, in Mahaney W. C. (ed.), Quaternary Paleoclimates, p. 85-105.

LAWSON, D. E. (1979): A sedimentological analysis of the western terminus of the Matanuska Glacier, Alaska, U.S. Army Cold Regions Research and Engineering Laboratory, Report No. 79-9, 122 p.

__ (1981): Distinguishing characteristics of diamictons at the margin of the Matanuska Glacier, Alaska. Annals of Glaciology, Vol. II, p. 78-84.

LUCKMAN, B. H. and OSBORN, G. D. (1979) : Holocene glacier fluctuations in the middle Canadian Rocky Mountains, Quaternary Research, Vol. XI, No. 1, p. 52-77.

LEVSON, V. M. (1986): Quaternary sedimentation and stratigraphy of montane glacial deposits in parts of Jasper National Park, Canada, M.Sc. Thesis, University of Alberta, Edmonton, $187 \mathrm{p}$.

MOUNTJOY, E. W. and PRICE, R. A. (1985) : Geology, Jasper, Alberta, Geological Survey of Canada Map 1611a, scale 1:50,000.

PRICE, R. A. and MOUNTJOY, E. W. (1970): Geologic structure of the Canadian Rocky Mountains between Bow and Athabasca rivers - A progress report, Geological Association of Canada Special Paper, No. 6, p. 7-25.

PROUDFOOT, D. N. (1985): A lithostratigraphic and genetic study of Quaternary sediments in the vicinity of Medicine Hat, Alberta, Ph.D. Thesis, Department of Geology, University of Alberta, Edmonton, $248 \mathrm{p}$.

RUST, B. R. (1984): Coarse alluvial deposits, In Walker R. (ed.), Facies Models, Second Edition, Geological Association of Canada, Geoscience Canada Reprint Series 1, p. 53-69.

SHAW, J. (1982): Melt-out till in the Edmonton area, Alberta, Canada, Canadian Journal of Earth Sciences, Vol. 19, p. 1548-1569.

WALKER, R. G. (1984): General introduction: facies, facies sequences and facies models, in Walker, R. G. (ed.), Facies Models Second Edition, Geological Association of Canada. Geoscience Canada Reprint Series 1, p. 1-11. 